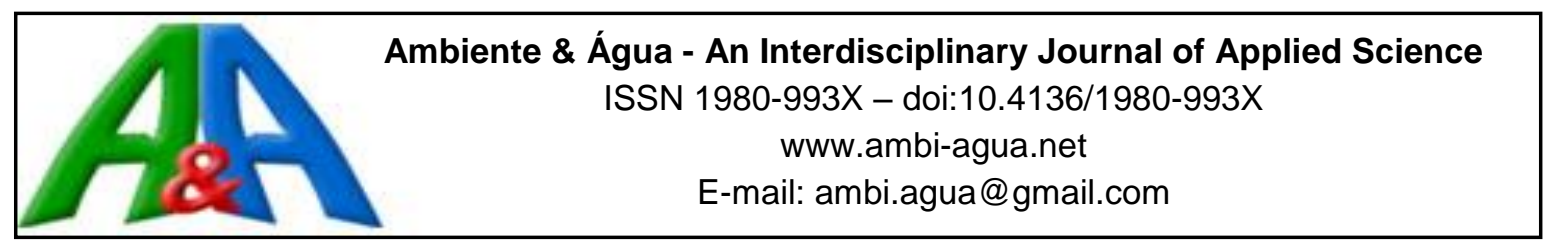

\title{
Analysis of water leached from soil treated with leachate from plant biomass ash
}

\author{
doi:10.4136/ambi-agua.2108
}

Received: 04 Mar. 2017; Accepted: 19 Jun. 2017

\author{
Everton Skoronski $^{1 *}$; Mylena Fernandes²; Diego Bitencourt Machado²; \\ Diego Hoefling Souza ${ }^{1}$; Aline Rodrigues ${ }^{3}$; Maurício Vicente Alves ${ }^{3}$ \\ ${ }^{1}$ Universidade do Estado de Santa Catarina (UDESC), Lages, SC, Brasil \\ Departamento de Engenharia Ambiental e Sanitária \\ ${ }^{2}$ Universidade Federal de Santa Catarina (UFSC), Florianópolis, SC, Brasil \\ Departamento de Engenharia Química e Engenharia de Alimentos \\ ${ }^{3}$ Universidade do Oeste de Santa Catarina (UNOESC), Xanxerê, SC, Brasil \\ Departamento de Agronomia \\ *Corresponding author: e-mail: skoronski@cav.udesc.br, \\ mylena.fernandes@gmail.com, diegobmachado@hotmail.com, \\ diego.hoefling@gmail.com, aline.rodrigues@unoesc.edu.br, \\ mauriciovicente@gmail.com
}

\begin{abstract}
This work analyzed water leached from soil treated with leachate from plant biomass ash. The ash was generated by industrial boilers used in the pulp and paper industry. Experiments were carried out in columns filled with soil, and the ash was then added to the soil to simulate field conditions. The ash was applied at 30 and 60 tons per hectare rate. The simulated rainwater was prepared for three scenarios: $\mathrm{pH} 3.0,6.5$ and 8.0. Each leaching experiment simulated an annual precipitation of $2,045 \mathrm{~mm}$. The results showed that the parameter that demands more attention is aluminum concentration. In this context, in acidic conditions ( $\mathrm{pH} \mathrm{3.0)}$ and with a significant amount of ash added (60 tons per hectare), the level of aluminum may reach the maximum level for drinking water. Despite the potential impact of aluminum, the use of ash from plant biomass in soil for agricultural purposes may serve as an alternative strategy for disposal of this waste.
\end{abstract}

Keywords: by-product, groundwater, paper and pulp industry, waste management.

\section{Análise da água lixiviada do solo tratado com lixiviação de cinzas de biomassa vegetal}

\section{RESUMO}

O objetivo principal deste trabalho foi estudar o impacto ambiental da aplicação de cinzas de biomassa vegetal no solo e os efeitos sobre a qualidade da água após a lixiviação. As cinzas são geradas por caldeiras industriais usadas na indústria de celulose e papel. Os experimentos foram realizados em colunas preenchidas com solo e, em seguida, as cinzas foram adicionadas sobre o solo para simular condições de campo. As cinzas foram aplicadas em quantidades iguais em uma taxa de 30 e 60 toneladas por hectare. A água da chuva foi preparada para simular três cenários: pH 3,0; 6,5 e 8,0. Cada experimento de lixiviação foi realizado para simular uma precipitação anual de $2.045 \mathrm{~mm}$. Os resultados mostraram que o parâmetro principal que exige 
mais atenção é a concentração de alumínio. Neste contexto, em condições ácidas (pH 3,0) e com uma grande quantidade de cinzas adicionadas (60 toneladas por hectare), o nível de alumínio no lixiviado pode atingir o nível máximo de água potável. Apesar do potencial impacto do alumínio, a adição de cinzas da biomassa vegetal no solo para a agricultura pode servir como uma estratégia alternativa para uso deste resíduo.

Palavras-chave: gestão de resíduos, indústria de papel e celulose, lixiviação do solo.

\section{INTRODUCTION}

The pulp and paper production industry contributes significantly to Brazilian development by having the lowest production costs in the world. Brazil is the fourth largest pulp producer and the ninth largest paper producer in the world, and has the fifteen-largest consumer market (Bracelpa, 2012). In light of these favorable economic conditions, the industry has sought to ensure sustainability for the various production components, especially the value and the use of the industrial waste. The waste from pulp and paper companies in Brazil is a product of the ubiquitous use of forest biomass as a fuel source. The burning of the forest biomass generates ash as a by-product, which requires adequate management in its disposal to avoid environmental problems.

The use of plant biomass to produce energy is ideal due to population growth and the current demand for sustainable energies, which made "shifting cultivation" an unsustainable system. Soil is used intensively in modern agriculture, requiring a replenishment of the nutrients removed with the harvest, which are chemical or organic in origin. The continuous and intense cultivation of agricultural areas creates an imbalance in soil fertility and mineral deficiencies because the majority of the soils in Brazil have low natural fertility (Prado et al., 2012). These deficiencies could be corrected with the use of chemical nutrients, or a more economical and environmentally friendly alternative, such as the use of ash from plant biomass. The use of ash from plant biomass is an appropriate way to use such residue in addition to contributing to soil fertility, as it is found in large quantities (Pitman, 2006).

The ash is composed of unknown amounts of macro and micronutrients, which should be analyzed by specific criteria. The presence of nutrients in ash has the potential to fertilize and to correct soil acidity (Melese et al., 2015). In this context, studies are needed to understand the composition of the ash, and to determine the proper quantities and the effects of ash applied to the soil, subsoil, plants, feasibility of use (Ramos et al, 2016), and effects on water in the subsoil. On the other hand, indiscriminate or excessive use of the ash may cause problems (Quirantes et al., 2016). When considering the importance of cationic balance to plant development, nutritional imbalance provoked by inadequate doses of ash can impair cultivation (Mandre, 2006).

In addition to the adverse effects on plants, the leaching of chemical compounds associated with the application of ash to soils may affect water quality. Studies related to the application of plant biomass ash to soil are scarce, especially as related to its impact on water quality. Thus, the objective of the present study was to describe the effects of applying plant biomass ash to soil by analyzing the quality of water leached from soil that received the ash.

\section{MATERIALS AND METHODS}

\subsection{Sample collection and characterization of the soil}

The soil used in this study was collected in the municipality of Xanxerê (Santa Catarina/Brazil). The soil originated from the geological formation of the Serra Geral (Brazil); the material of origin is basalt. The terrain of the collection site is undulated, presents good drainage, with no apparent erosion. The original vegetation is seasonal semi-deciduous forests, 
a mussununga ecoystem, currently with cultivation of annual species. The soil was characterized as Red Nitosol Dystrophic Latosol, according to the Brazilian System of Soil Classification.

\subsection{Sample collection and characterization of the ash}

The ash used in this study was placed in an industrial water tube boiler that uses plant biomass (Pinus taeda L. e de Eucalyptus sp.) chips as fuel. The boiler contains a rotating grate and produces 90 tons $\mathrm{h}^{-1}$ of steam, operating at a pressure of 60 bar. Two samples were taken from the ash storage container, and a $10 \mathrm{~kg}$-sample composed of four $2.5 \mathrm{~kg}$-fractions from different samples was prepared for the study. The ash was characterized according to the guidelines of ABNT/NBR 10004:2004 (ABNT, 2014a) for the characterization of solid wastes. The tests recommended by the guidelines of ABNT/NBR 10005:2004 (ABNT, 2014b) and 10006:2004 (ABNT, 2014c) were carried out for leaching and solubility, respectively. These analyses of the two samples were conducted in an outside laboratory with accreditation from ISO 17025:2005 and were expressed as a mean.

\subsection{Assembly and operation of the leaching columns}

To simulate leaching, columns were mounted as shown in Figure 1. For the material, PVC tubes and draining accessories were used with a nominal diameter of $100 \mathrm{~mm}$. Soil samples were inserted in the column to compose a single layer of $100 \mathrm{~cm}$, combining ten layers of soil sampled every $10 \mathrm{~cm}$ and measured starting from the surface to simulate the soil profile one meter deep. The bottom of the column was composed of a nylon screen with a $1.5 \mathrm{~mm}$ mesh and a $10 \mathrm{~cm}$ layer of inert crushed stone "No. 3" as a means of support. Doses of ash equivalent to 30 to 60 tons per hectare were added at the top. An experiment without the application of the ash was considered as the control. A fast-filtering filter paper was added above the ash and the soil (control) to evenly distribute the water fed for the leaching.

To evaluate the leaching water, simulated rainwaters were prepared with the addition of a mix of $\mathrm{H}_{2} \mathrm{SO}_{4}$ and $\mathrm{HNO}_{3}$ at a ratio of 1:1 (moles) as described in Agourakis et al. (2006) to attain a $\mathrm{pH}$ equal to 3.0. The experiment was also carried out with rainwater at a $\mathrm{pH}$ of 6.5 and water with a $\mathrm{pH}$ of 8.0, adjusted with ammonium hydroxide. The volume of rainwater applied to the columns was based on the average annual rainfall index, which is $2,045 \mathrm{~mm}$ for the municipality of Xanxerê (Santa Catarina), representative of a potential location for the application of ash. The simulated rainwater was fed to the column with peristaltic pumps, Model EX-P (Exatta ${ }^{\circledR}$, Brazil). The unit of volume of the solution applied was the pore volume, corresponding to the volume of water necessary to occupy the empty spaces of the soil sample. Leaching water was initially added, corresponding to the pore volume of the soil sample, and kept into the column for 24 hours. After the initial application of the leaching water, five pore volumes of the leaching water were passed through the columns, equivalent to 1 year of rainfall. Samples were taken from the leachate of each pore volume for analysis of the chemical elements leached through the column for the type of rainwater. Three columns were assembled for each treatment to obtain the data in triplicate. The conditions with the $\mathrm{pH}$ of 3.0 were carried out only with the control and the addition of 60 tons per hectare, with the goal of evaluating only an extreme condition. 

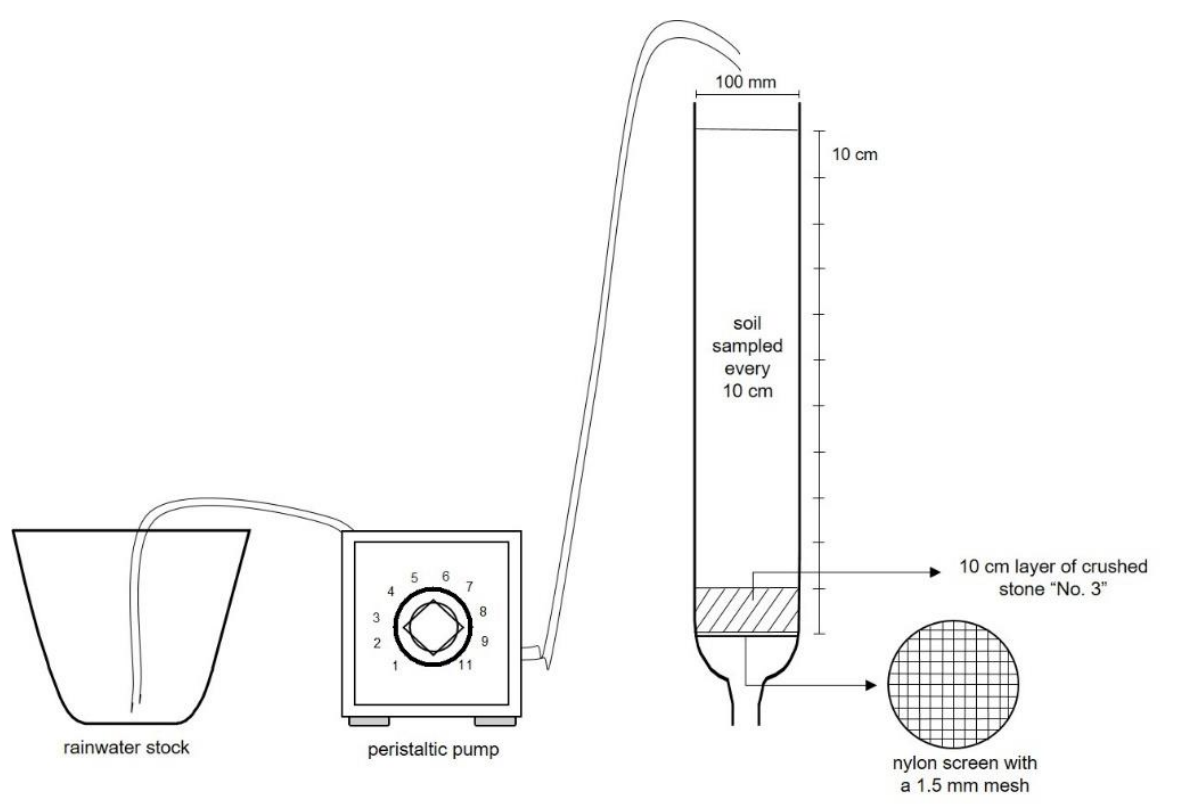

Figure 1. Experimental assembly for the leaching tests.

\subsection{Physical-chemical analyses of the leachate}

For the chemical analysis of the leaching, the samples were initially passed through a vacuum filtration system (Merck/Millipore ${ }^{\circledR}$, Germany) with circular membranes $(47 \mathrm{~mm})$ of cellulose acetate $(0.45 \mu \mathrm{m})$ to remove the suspended solids in the sample. The $\mathrm{pH}$, total dissolved solids, and dissolved oxygen were read using a multi-parameter probe, Model HI 98194 (Hanna ${ }^{\circledR}$, USA).

The true color, chemical oxygen demand (COD), ammonia nitrogen $\left(\mathrm{N}-\mathrm{NH}_{3}\right)$, nitrate $\left(\mathrm{N}^{-\mathrm{NO}_{3}}{ }^{-}\right)$, total phosphorus $(\mathrm{P})$ and chlorides $\left(\mathrm{Cl}^{-}\right)$were analyzed according to the standard methods for water analysis (APHA et al., 2005). The true color analysis was carried out using the $2120 \mathrm{C}$ Method, for the COD the $5220 \mathrm{D}$ Method, for the $\mathrm{N}-\mathrm{NH}_{3}$ the $4500-\mathrm{NH}_{3} \mathrm{~F}$ Method, for the ${\mathrm{N}-\mathrm{NO}_{3}}^{-}$the 4500- $\mathrm{NO}_{3}{ }^{-}$Method, for the $\mathrm{P}$ the 4500-P Method, and for the $\mathrm{Cl}^{-}$the 4500-

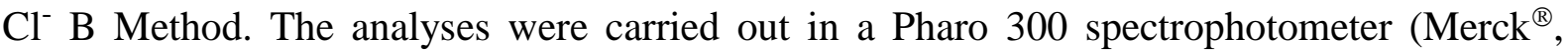
Germany).

The metals (aluminum, barium, beryllium, bismuth, calcium, cadmium, cobalt, chromium, copper, lead, iron, gallium, lithium, magnesium, potassium, selenium, sodium, and zinc) and boron were analyzed using an optical emission spectrometer (ICP-OES) Model OPTIMA 8300 (Perkin Elmer ${ }^{\circledR}$, USA). This equipment uses flat induction plates (Flat Plate ${ }^{\mathrm{TM}}$ plasma technology) instead of the traditional helical load coil and dual-view ICP-OES with two solid-state SCD detectors covering the spectral range from 163-782 $\mathrm{nm}$. The samples were acidified with $\mathrm{HNO}_{3}$ P.A. to a concentration of $5 \%(\mathrm{v} / \mathrm{v})$ for further detection in the equipment.

\section{RESULTS AND DISCUSSION}

\subsection{Characterization of the ash}

To characterize the crude sample of ash, tests of corrosivity, flammability, pathogenicity, reactivity, and toxicity were carried out. The results obtained were negative for all of the trials, which designates the ash as a Class II waste (ABNT, 2014a). The toxicity test was carried out through the leaching test according to NBR 10005:2004 (ABNT, 2014b). Arsenic, barium, cadmium, lead, total chromium, fluoride, mercury, selenium, and silver were analyzed, most of which presented concentrations below the detection limit for the method. Lead was the exception, and showed a concentration of $0.2 \mathrm{mg} \mathrm{L}^{-1}$, which is below the maximum value allowed for the assay $\left(1.0 \mathrm{mg} \mathrm{L}^{-1}\right)$ for the leaching test. 
Since the waste was classified as non-hazardous, the solubility test was carried out according to NBR 10006:2004 (ABNT, 2014c) to classify the waste as non-inert (Class IIA) or inert (Class IIB) (ABNT, 2014a). Among the various parameters analyzed, only aluminum showed a concentration of solubility in the water above the recommended maximum value to be considered as inert waste. Thus, the waste was classified as non-inert and, therefore, Class IIA (non-hazardous and non-inert) (ABNT, 2014a).

\subsection{Leaching experiments}

To prepare the rainwater samples, preliminary experiments were carried out to characterize the water of the study area (Xanxerê - SC). Rains with a pH of 5.90 to 8.77 were observed. The $\mathrm{pH}$ of rainwater is linked to the activities carried out in the region. The rain tends to show acidic characteristics in urban areas and industrial parks (Migliavacca et al., 2004). Rain tends to be more alkaline in regions with a predominance of agricultural activities (Cunha and Dalmago, 2000). Previous studies have also correlated the alkaline $\mathrm{pH}$ of the rain with the presence of $\mathrm{Ca}$ and $\mathrm{Mg}$ in the dust of the atmosphere (Zhang et al., 2002). In this context, the $\mathrm{pH}$ observed in the rainwater of the study area was considered alkaline and due to this region being strongly agricultural. Furthermore, the soil analysis showed a high concentration of $\mathrm{Ca}$ and $\mathrm{Mg}$ ions, which influence this behavior. Thus, to enable a more comprehensive analysis of the effect of rainwater quality on leaching, experiments were carried out in extremely acidic conditions (treatments with $\mathrm{pH} 3.0$ ). Figure 2 shows the dynamic in the variation of physical-chemical parameters related to the quality of the leaching water. The experiments were carried out for three different levels of $\mathrm{pH}$ of the rainwater, and different quantities of ash applied to the soil.

In relation to the $\mathrm{pH}$ (Figure $2 \mathrm{~A}$ ), the leaching water was observed to maintain $\mathrm{pH}$ in the range 5.5 to 6.5 , independent of the initial $\mathrm{pH}$ of the rainwater that passed through the soil column. This observation is linked to the buffer effect created by the soil in question. In this context, ions such as $\mathrm{K}^{+}, \mathrm{Ca}^{2+}$ and $\mathrm{Mg}^{2+}$ present in the soil have the capacity to execute the ion exchange with $\mathrm{H}^{+}$ions (Manahan, 1994). Furthermore, the presence of residual alkalinity $\left(\mathrm{HCO}_{3}{ }^{-}\right.$and $\left.\mathrm{H}_{2} \mathrm{PO}_{4}\right)$ generates a buffer system consisted of, $\mathrm{HCO}_{3}{ }^{-} / \mathrm{H}_{2} \mathrm{CO}_{3} / \mathrm{CO}_{2}$ as an example, according to the Reaction 1.

$$
\mathrm{CaCO}_{3(s)}+\mathrm{H}_{3} \mathrm{O}_{(a q)}^{+} \rightarrow \mathrm{Ca}_{(a q)}^{2+}+\mathrm{HCO}_{3(a q)}^{-}+\mathrm{H}_{2} \mathrm{O}_{(l)}
$$

For total dissolved solids, the World Health Organization, WHO, (2011) indicates the maximum concentration to be $600 \mathrm{mg} \mathrm{L}^{-1}$ for drinking water. The concentrations of total dissolved solids for the rainwaters with $\mathrm{pH} 6.5$ and 8.0 did not exceed $35.5 \mathrm{mg} \mathrm{L}^{-1}$ in any of the tests. Even for an extreme situation with a $\mathrm{pH}$ of 3.0, the concentration of the dissolved solids in the leaching water reached a mean value of $157 \mathrm{mg} \mathrm{L}^{-1}$.

The true color for drinking water should present a maximum value of $15 \mathrm{TCU}$ (true color unit) according to WHO (2011). The true color test indicates the presence of inorganic ions and dissolved organic material. The true color in the tests of the present study was below 17 TCU (Figure 2B), indicating that the leachate was slightly impacted by the $\mathrm{pH}$ of the rainwater and/or the dose of the ash. In addition, the experiments with ash addition and the blank tests were similar. Furthermore, the chemical oxygen demand (COD) was measured for all treatments, and the results showed values below $10 \mathrm{mg} \mathrm{L}^{-1}$, indicating that there is no significant solubility of organic material in the water. The COD was derived by measuring the dissolved oxygen, which showed no significant difference between treatments.

Nitrate is an important ion that may harm human health. Thus, its concentration according to the standard requirement for water drinking (WHO, 2011) is $50 \mathrm{mgNO}_{3} \mathrm{~L}^{-1}$ or approximately $10 \mathrm{mgN}-\mathrm{NO}_{3}{ }^{-} \mathrm{L}^{-1}$. Water treatment plants do not have the technology to remove nitrate due to its high solubility, requiring control mechanisms to remain at the source. Higher rates of certain 
cancers are reported in people who ingest high doses of this anion (Wick et al., 2012). The results indicate that the soil used in the present study releases concentrations above the limit previously specified during the passing of one- and two pore volumes of leaching water. This behavior, however, is not exclusive to the treatments that received the ash, since the control experiments showed the same behavior (Figure 2C). Previous studies demonstrated that nitrate has high mobility in soil, mainly negatively charged soil (Oliveira and Mattiazzo, 2001). The presence of nitrate in soil can be associated with the use of nitrogenous mineral fertilizers (Araújo et al., 2004). The ash in the present study did not contribute to the increased load of this ion in the leachate. The analysis of ammoniac nitrogen was also carried out and found values less than $0.1 \mathrm{mg} \mathrm{L}^{-1}$, suggesting that the predominant form of nitrogen in the soil could be the nitrate. The quality of drinking water requires concentrations below $1.5 \mathrm{mg} \mathrm{L}^{-1}$, according to WHO (2011).

For chlorides, the standard for drinking water according to the cited references is $250 \mathrm{mg} \mathrm{L}^{-1}$. This value was not exceeded in any of the leaching water samples of the present study (Figure 2D), suggesting that there is no influence on the salinity of the water leaching through the column due to the function of the chlorides, even with the addition of the ash. For phosphorus, the concentration limit of the method was $0.02 \mathrm{mg} \mathrm{L}^{-1}$, which was also not exceeded in any of the tests in the present study.
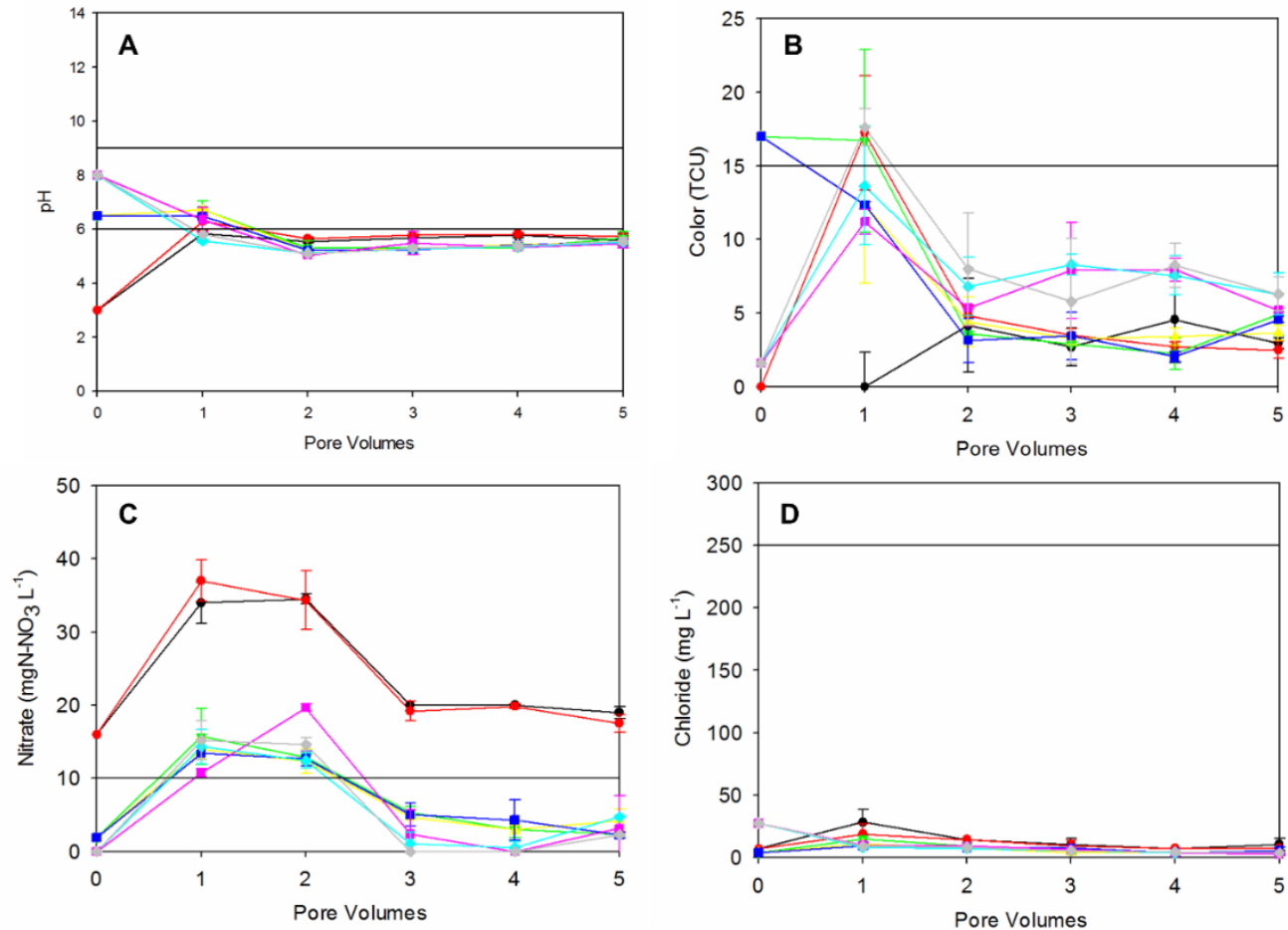

Figure 2. Physicochemical parameters of the leaching as a function of the pore volumes. The precipitation was $2,045 \mathrm{~mm}$ per year. The symbols represent blank at $\mathrm{pH} 3.0 ; \bigcirc 60$ tons/ha at $\mathrm{pH} 3.0 ; \boldsymbol{\nabla}$ blank at $\mathrm{pH} 6.5 ; \triangle 30$ tons/ha at $\mathrm{pH}$ $6.5 ; \square 60$ tons/ha at $\mathrm{pH} 6.5 ; \square$ blank at $\mathrm{pH} 8.0 ; \diamond 30$ tons/ha at $\mathrm{pH} 8.0 ; \diamond 60$ tons/ha at $\mathrm{pH} 8.0 ;$ - reference values (WHO, 2011).

In addition to these parameters, various metals and boron were also analyzed. The following metals and boron showed concentrations below the detection limit of the analytical method $\left(\mathrm{mg} \mathrm{L}^{-1}\right)$, indicated in parentheses, as follows: cadmium (0.006), cobalt (0.009), chromium (0.028), copper (0.027), boron (0.056), barium (0.006), beryllium (0.046), bismuth (0.155), iron (0.023), gallium (0.015), lithium (0.0002), lead (0.085), selenium (0.454) and zinc 
(0.016). Sodium was detected, but no difference was found between the control treatment and the experiments that received the ash.

The graphs shown in Figure 3 represent the increase in measured concentrations of the leaching water due filtration through the soil columns of the control and those that received the ash.
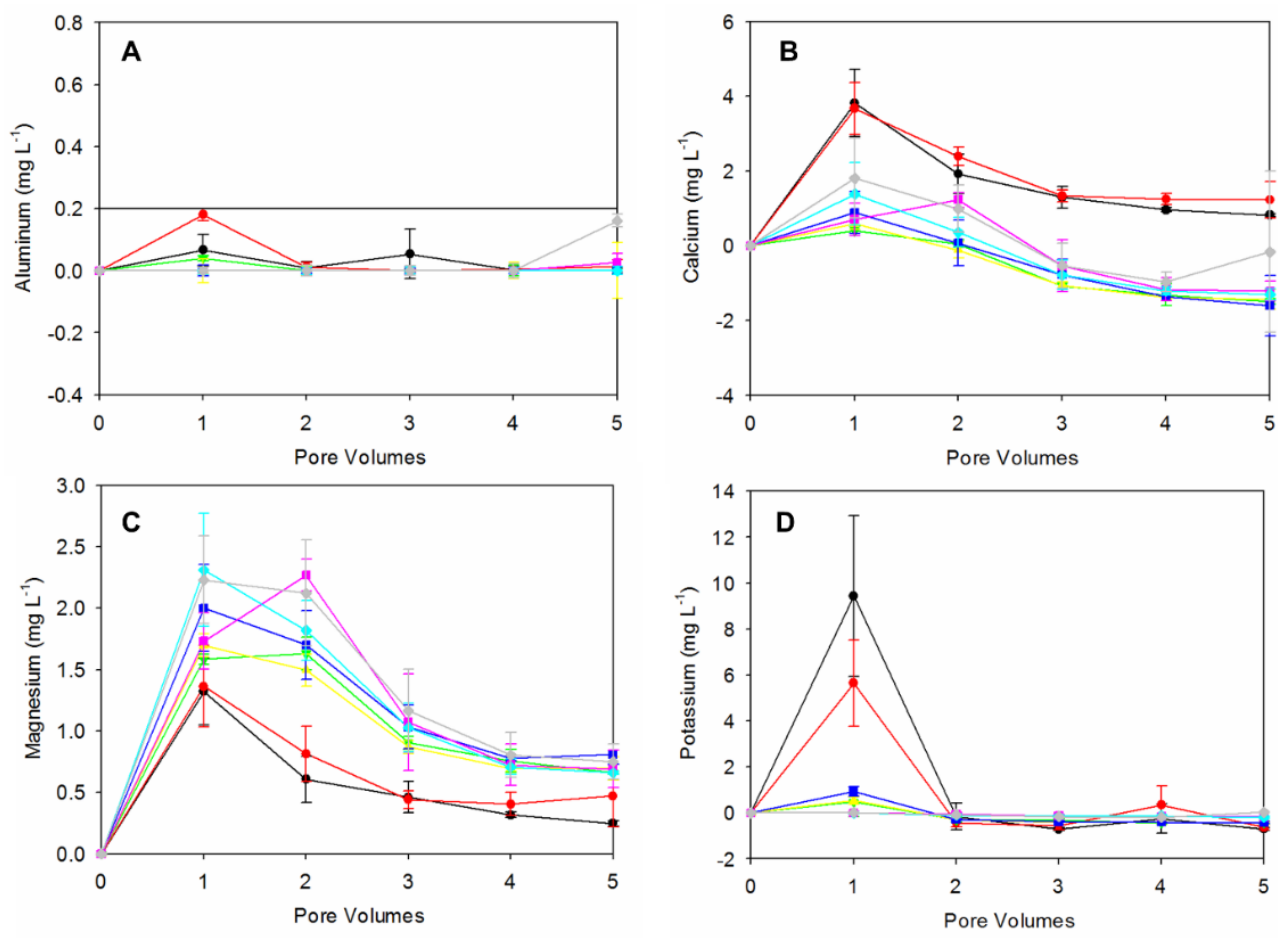

Figure 3. Variation in the metal concentration of the leaching from the soil. The precipitation was $2,045 \mathrm{~mm}$ per year. The symbols represent 0 blank at $\mathrm{pH} 3.0$; $\bigcirc 60$ tons/ha at $\mathrm{pH} 3.0 ; \boldsymbol{\nabla}$ blank at $\mathrm{pH} 6.5 ; \triangle 30$ tons/ha at $\mathrm{pH} 6.5 ; \mathbf{\square} 60$ tons/ha at $\mathrm{pH} 6.5 ; \square$ blank at $\mathrm{pH} 8.0 ; \diamond 30$ tons/ha at $\mathrm{pH} 8.0 ; \diamond 60$ tons/ha at $\mathrm{pH} 8.0$; — reference values (WHO, 2011).

The aluminum was observed to be pulled by the rainwater in acidic conditions ( $\mathrm{pH}$ 3.0), generating an increase of $0.19 \mathrm{mg} \mathrm{L}^{-1}$ in the average concentration (Figure 3A). This was detected with the application of 60 tons per hectare of ash. For the control, the increase was on average $0.07 \mathrm{mg} \mathrm{L}^{-1}$. Whereas studies claim that a health-based value would be $0.9 \mathrm{mg} \mathrm{L}^{-1}$ for drinking water, water treatment facilities are able to produce water containing less than 0.2 $\mathrm{mg} \mathrm{L}^{-1}$ of aluminum, which is the standard value for drinking water (FAO and WHO, 2006). Thus, considering the characteristics observed for the ash, the aluminum is the ion that can be extractable and should thus receive special attention. For the most alkaline conditions used in the present study, the aluminum was not observed to be pulled through the columns, perhaps due to the speciation of the aluminum in less soluble forms. For the $\mathrm{pH}$ of 8.0 and the application of ash at 60 tons per hectare, however, a trend of aluminum extraction was observed for the passing of greater than four pore volumes. In these conditions, the excess aluminum added to the medium through the ash can promote the movement of this ion, enabling the detection of its concentration in the leachate.

Calcium (Figure 3B), magnesium (Figure 3C) and potassium (Figure 3D) were also observed in the leachate for the more acidic condition ( $\mathrm{pH}$ 3.0). This effect may be related to the neutralization capacity of the soil and ash, since these cations represent a basic portion of the medium, and thus have the capacity to neutralize the acidity of the leachate. Furthermore, 
the cation exchange capacity (CEC) decreases in soils with an acidic $\mathrm{pH}$, leaving the cations available for leaching.

The results obtained in the present study demonstrate the feasibility of the activity in question. Few studies have reported the effects of the use of ash from plant biomass on soil and the consequential environmental impact, in the instant case, on water. For example, other authors (Maeda et al., 2010) used levels of ash of up to 80 tons per hectare. Contaminants such as $\mathrm{As}, \mathrm{Cu}, \mathrm{Cr}$ and the total nutrients such as $\mathrm{P}, \mathrm{Na}, \mathrm{K}, \mathrm{Ca}, \mathrm{Mg}, \mathrm{Al}$ and $\mathrm{P}$ were evaluated. The results demonstrated that the concentrations obtained in the leachate within the maximum values allowed by the ordinance of the health ministry of Brazil for potability.

\section{CONCLUSION}

The plant biomass ash considered in the present study was classified as non-hazardous waste, with the leaching of aluminum representing greatest potential negative impact after application to soil. This concern, however, is based on the extreme conditions of acidic rainwater $(\mathrm{pH}=3.0)$ and high doses of ash applied to the soil (60 tons per hectare). Thus, the application of plant biomass ash to soil appears to be a sustainable alternative for the disposal of this by-product of the pulp and paper industries in the southern region of Brazil. This activity avoids the disposal of ash in landfills for Class IIA wastes, ultimately increasing the life-use of the ash. The paper only analyzed the impact on leachate after the application of ash to soil. Therefore, additional studies must be performed to determine sustainable alternative(s) in view of potential impacts, such as those on soil for example.

\section{ACKNOWLEDGEMENTS}

The authors would like to thank Irani Celulose for the financial support for this project, National Counsel of Technological and Scientific Development for the scholarship (Grant $\mathrm{n}^{\circ}$ 800628/2015), and to the soil analysis laboratory of CAV/UDESC for carrying out the ICP analyses.

\section{REFERENCES}

ASSOCIAÇÃO BRASILEIRA DE NORMAS TÉCNICAS - ABNT. NBR 10004 - Resíduos sólidos: classificação. Rio de Janeiro, 2004a.

ASSOCIAÇÃO BRASILEIRA DE NORMAS TÉCNICAS - ABNT. NBR 10005 Procedimentos para obtenção de extrato lixiviado de resíduos sólidos. Rio de Janeiro, 2004b.

ASSOCIAÇÃO BRASILEIRA DE NORMAS TÉCNICAS - ABNT. NBR 10006 Procedimento para obtenção de extrato solubilizado de resíduos sólidos. Rio de Janeiro, 2004c.

AGOURAKIS, D. C. et al. Comportamento de zinco e manganês de pilhas alcalinas em uma coluna de solo. Química Nova, v. 29, n. 5, p. 960-964, 2006. http://dx.doi.org/10.1590/S0100-40422006000500014

AMERICAN PUBLIC HEALTH ASSOCIATION - APHA; AMERICAN WATER WORKS ASSOCIATION - AWWA; WATER ENVIRONMENT FEDERATION - WEF. Standard methods: for the examination of water and wastewater. 21st. ed. Washington, DC, 2005. 
ARAÚJO, A. R. DE et al. Movimentação de nitrato e amônio em colunas de solo. Ciência e Agrotecnologia, v. 28, n. 3, p. 537-541, 2004. http://dx.doi.org/10.1590/S141370542004000300008

ASSOCIAÇÃO BRASILEIRA DE CELULOSE E PAPEL - BRACELPA. Dados do setor. São Paulo, fevereiro 2012.

CUNHA, G. R. DA; DALMAGO, G. A. Informações sobre pH de águas de chuva em Passo Fundo, RS. Revista Brasileira de Agrometeorologia, v. 8, n. 2, p. 325-329, 2000.

FOOD AND AGRICULTURE ORGANIZATION - FAO; World Health Organization - WHO. Aluminium (from all sources, including food additives). In: FAO; WHO. Evaluaion of certain food additives and contaminants: Sixty-seventh report of the Joint FAO/WHO Expert Committee on Food Additives. Rome, 2006. p. 33-44.

MAEDA, S.; COSTA, E. R. O.; SILVA, H. D. Uso de resíduos da fabricação de celulose e papel e da reciclagem de papel. Dados eletrônicos. Colombo: Embrapa Florestas, 2010.

MANAHAN, S. E. Environmental chemistry. 6th. ed. Boca Raton: Lewis Publishers, 1994.

MANDRE, M. Influence of wood ash on soil chemical composition and biochemical parameters of young Scots pine. Proceedings of the Estonian Academy of Sciences: Biology, Ecology, v. 55, p. 91-107, 2006.

MELESE, A.; YLI-HALLA, M.; YITAFERU, B. Effects of Lime, Wood Ash, Manure and Mineral P Fertilizer Rates on Acidity Related Chemical Properties and Growth and P Uptake of Wheat (Triticum aestivum L.) on Acid Soil of Farta District, Northwestern Highlands of Ethiopia. International Journal of Agriculture and Crop Sciences, v. 8, n.2, p. 256-269, 2015.

MIGLIAVACCA, D. et al. Study of chemical elements in atmospheric precipitation in South Brazil. Atmospheric Environment, v. 38, n. 11, p. 1641-1656, 2004. https://doi.org/10.1016/j.atmosenv.2003.11.040

OLIVEIRA, F. C.; MATTIAZZO, M. E. Mobilidade de metais pesados em um Latossolo Amarelo distrófico tratado com lodo de esgoto e cultivado com cana-de-açúcar. Scientia Agricola, v. 58, n. 4, p. 807-812, 2001. http://dx.doi.org/10.1590/S010390162001000400024

PITMAN, R. M. Wood ash use in forestry - A review of the environmental impacts. Forestry, v. 79, n. 5, p. 563-588, 2006. https://doi.org/10.1093/forestry/cpl041

PRADO, R. B. et al. Mapping Soil Fertility at Different Scales to Support Sustainable Brazilian Agriculture. World Academy of Science, Engineering and Technology, v. 69, p. 844$852,2012$.

QUIRANTES, M. et al. Soil-nutrient availability affected by different biomass-ash applications. Journal of Soil Science and Plant Nutrition, v. 16, n. 1, p. 159-163, 2016. http://dx.doi.org/10.4067/S0718-95162016005000012

RAMOS, S. J. et al. Rare Earth Elements in the Soil Environment. Current Pollution Reports, v. 2, n. 1, p. 28-50, 2016. http://dx.doi.org/10.1007/s40726-016-0026-4

WORLD HEALTH ORGANIZATION - WHO. Guidelines for drinking-water quality. 4th. ed. Geneva, 2011. 
WICK, K.; HEUMESSER, C.; SCHMID, E. Groundwater nitrate contamination: Factors and indicators. Journal of Environmental Management, v. 111, p. 178-186, 2012. https://doi.org/10.1016/j.jenvman.2012.06.030

ZHANG, D. D. et al. Alkaline rains on the Tibetan Plateau and their implication for the original $\mathrm{pH}$ of natural rainfall. Journal of Geophysical Research Atmospheres, v. 107, n. 14, p. 1-6, 2002. http://dx.doi.doi.org/10.1029/2001JD001332 